\title{
HTLV-1 bZIP factor induces systemic inflammations in vivo
}

\author{
Nanae Taguchi ${ }^{*}$, Yorifumi Satou' ${ }^{1}$ Koichi Ohshima², Masao Matsuoka ${ }^{1}$ \\ From 15th International Conference on Human Retroviruses: HTLV and Related Viruses \\ Leuven and Gembloux, Belgium. 5-8 June 2011
}

Human T-cell leukemia virus type 1 (HTLV-1) causes both neoplastic and inflammatory diseases, which include HTLV-1 associated myelopathy/tropic spastic paraparesis and uveitis. Recently, we have reported that transgenic expression of HTLV-1 bZIP factor (HBZ) in $\mathrm{CD} 4+\mathrm{T}$ cells caused dermatitis and alveolitis in mice. In this study, we investigated the production of cytokines in HBZ transgenic (HBZ-Tg) mice to elucidate the mechanism of its pro-inflammatory phenotype. IFN- $\gamma$ production in $\mathrm{CD} 4+\mathrm{T}$ cells was remarkably increased in splenocytes, lungs and PBMCs from HBZ-Tg compared with non-transgenic littermates, whereas there was no difference in levels of IL-4 and IL-17. We also found that production of IFN- $\gamma$ was remarkably enhanced in CD4+Foxp3- fraction.

Recent studies have reported that CD4+Foxp3+ T cells are not terminally differentiated but have a plasticity to convert to other $\mathrm{T}$ cell subsets. Induced regulatory $\mathrm{T}$ cells (iTreg) tend to lose Foxp3 expression, and may acquire an effector phenotype accompanied by the production of inflammatory cytokines, such as IFN- $\gamma$. We observed that the percentage of naturally occurring Treg cells was lower in HBZ-Tg mice than non-Tg mice, although total number of Treg was increased in HBZ-Tg mice. It is suggested that the enhanced generation of iTreg cells and instability of Foxp3 expression in HBZ-induced iTreg is a possible mechanism for increased number IFN- $\gamma$ producing cells in HBZ-Tg mice, leading to systemic inflammation.

\footnotetext{
Author details

${ }^{1}$ Institute for Virus Research, Kyoto University, Kyoto, 606-8507, Japan. ${ }^{2}$ Department of Pathology, Kurume University School of Medicine, Kurume, 830-0011, Japan.
}

\footnotetext{
* Correspondence: ntaguchi@virus.kyoto-u.ac.jp

${ }^{1}$ Institute for Virus Research, Kyoto University, Kyoto, 606-8507, Japan

Full list of author information is available at the end of the article
}

Published: 6 June 2011

doi:10.1186/1742-4690-8-S1-A8

Cite this article as: Taguchi et al.: HTLV-1 bZIP factor induces systemic inflammations in vivo. Retrovirology 2011 8(Suppl 1):A8.
Submit your next manuscript to BioMed Central and take full advantage of:

- Convenient online submission

- Thorough peer review

- No space constraints or color figure charges

- Immediate publication on acceptance

- Inclusion in PubMed, CAS, Scopus and Google Scholar

- Research which is freely available for redistribution

\section{() Biomed Central}

C Biomed Central

C 2011 Taguchi et al; licensee BioMed Central Ltd. This is an open access article distributed under the terms of the Creative Commons Attribution License (http://creativecommons.org/licenses/by/2.0), which permits unrestricted use, distribution, and reproduction in any medium, provided the original work is properly cited. 